\title{
TEACHING WRITING DESCRIPTIVE TEXT BY USING FACEBOOK AT SEVENTH GRADE SMPN 1 SEMEN
}

\author{
Qilya Esti Wahyuni, Ali Rohmad
}

\begin{abstract}
The purpose of this research is to find out whether Facebook is effective or not in teaching writing descriptive text. This research employed a quantitative approach of using true experimental. Meanwhile, the research using Post-test Only Control Design for writing skill. The research was conducted in the seventh grade of SMPN 1 Semen in academic year 2018/2019. This research using 2 class as the sample, experimental group and control group. To get the result of the research, this research using test. The mean score of experimental group is 72.50 in a good category. Meanwhile, the mean score of control group is 57.83 in fair category. The result of independent sample test show that there is significant difference between experimental group which is taught by using Facebook and control group which is not taught by using Facebook. The alternative hypothesis stated that Facebook is effective to be used in writing descriptive text at the seventh grade of SMPN 1 Semen.
\end{abstract}

Keywords: descriptive text, Facebook, writing

\section{INTRODUCTION}

Writing is a thinking process that can be planned and given with an unlimited number of revisions before its release (Brown, 2000:337). Writing is a combination of process and product of discovering ideas, putting them on paper and working with them until they are presented in manner that is polished and comprehensible to readers (Linse, 2003:98). In learning English writing is very important to support the students' ability to write correctly and can be understand by the readers. There are three general purposes of writing, and they can all occur in a single essay, although usually one of the purposes is dominant. Those are; to explain (educate, inform), to entertain (amuse, give pleasure), and to persuade (convince, change the reader's mind) (Reid, 2000:8). In this research to evaluate has categories, those are; content, organization, grammar, vocabulary and mechanics (Brown, 2007:214). The text use in this research was descriptive text. Descriptive text is a kind of text with a purpose to give information (Gerot \& Wignell, 1994:192). Description is about sensory experience-how something looks, sounds, tastes (Kane, 2000:352). It can be conclude that descriptive text is a kind of text that describes an object such as person, place, animal or thing in details with a purpose to give information to the readers. This research use Facebook as a learning media. Facebook is a social utility that connects us with the people, brands and organizations (Westminster, 2013:2). Facebook has many feature, those are wall profile, inbox, photo, group event, games, chat and blog. In 
this research using Facebook group as learning media in the class. Facebook groups is a feature that is available on the social networking site Facebook in which unlimited number of members are allowed to participate, communicate and interact via post and chat style for specific purpose (Yunus \& Salehi, 2012:87). Giving Facebook as media learning to the students is supposed to engage the students' in learning activities. The best way to bring courses to life and make learners more exciting, energetic, and enjoyable is by using social networking site in the learning (Friedman 2012:17). One of media that can be used in teaching writing descriptive text was Facebook.

\section{METHODOLOGY}

The objective of this research was to find whether Facebook is effective or not in teaching writing descriptive text in the seventh grade SMPN 1 Semen. This research employed a quantitative approach of using true experimental. Meanwhile, the researcher using Post-test Only Control Design for writing skill. This research used two classes, experimental and control group. There was no pretest given to either group. In the experimental class were taught by Facebook group and in the control class without using Facebook group. This research was conducted in the seventh grade of SMPN 1 Semen, class 7D as experimental group and 7E as control group. This school has located in Jl. Argowilis no. 78, Semen, Kediri. This research was conducted on April 2019. The instrument of this research was writing test. The test administered for experimental and control group was the same. The students were asked to write description about their house in a minimum 150 words. The time for doing the test was 45 minutes. The scoring follow the aspect of writing, such as: content (1-4), organization (1-4), grammar (1-4), vocabulary (1-4), mechanics (1-4). The research procedure of this research as following as;

In the first meeting, the researcher was explaining about the use of Facebook group in the class. The researcher also make group in Facebook, and invite the chief of the class to invite other friends in the group. The researcher give the rule about the Facebook group. The researcher decide the time they have to online in Facebook. In the Facebook group, the researcher give some explanation in a group post about descriptive text and the elements. The researcher trigger the student to ask in the comment box. Then, the researcher give them a task to write a text with minimum 130 words in the group post. The first topic is about living room. The students have to post their text or paragraph about their living room and their photo in the living room.

In the second meeting, the researcher give the correction of the paragraph that the students write in the post before. The students have to discuss about it in the class. After that, the students choose randomly to explain about their writing on the Facebook group in front of class. The researcher explain about descriptive text and the elements to remind the students in the class and Facebook group. The researcher trigger the students to ask what they don't know about the descriptive text and the elements. The researcher give the other topic as a task, the topic is about bedroom. Same as before, the students have to post their text and photo about their bedroom in the Facebook group, the words minimum 130 words. 
In the third meeting, the researcher give the correction of the paragraph that the students write in the post before. The students have to discuss about it in the class. After that, the students choose randomly to explain about their writing on the Facebook group in front of class. The researcher ask the knowledge of the students about descriptive text. The researcher give the other topic to be a task, the topic is about kitchen. Same as before, the students have to post their paragraph and photo about their best friend in the Facebook group, minimum 130 words.

The fourth meeting was test. The researcher explain about the topic before and discuss it with the student. The test held for 45 minutes. The researcher give a paper test to the students. The students have to describe their house in to a text. Students have to do the test as the teacher instruction. The words minimum 150.

\section{DATA ANALYSIS}

To measure the result of the test instrument, this research using validity, reliability, normality and independent sample test. The validity of instrument was using content validity and construct validity. The test was said have content validity if its contents constitute a representative sample of language skills, structure, etc., being tested. Beside that the content of instrument has to relevant with the purpose of the test. In this case, the content validity should refer to the Kurikulum 2013. Based on the standard competence of Kurikulum 2013, the students are expected to be able to write a simple text in the form of descriptive text. The content of items in testing using descriptive text.

Construct validity deals with the relationship between a test and a particular view of language and language learning (Johnson, 2001:303). In this research, the test had high construct validity since it contained prompt in form of indicator to measure students' skill in writing a descriptive text. The reliability of instrument result could be seen at the value of Cronbach's Alpha was 0.692. The instrument reliability criteria is in the range $0,61<\mathrm{r} \leq 0,80$. Based on the result it can be conclude the reliability is in the high criteria. The normality of instrument was shown in histogram. If the histogram had a peak, it meant the data could be included in normal distribution.

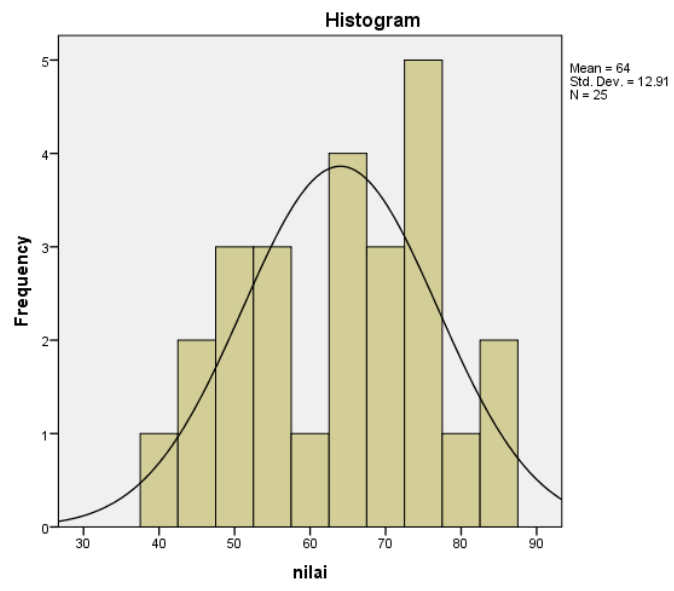


Based on the figure above, it can be concluded that the data of the students' writing achievement were various and distributed normally. It was proven by the peak that appeared. The result of test was measuring by using SPSS version 23. The result of the test shown below:

\begin{tabular}{|l|l|r|r|r|c|}
\multicolumn{1}{|c|}{ Group Statistics } \\
\cline { 2 - 6 } & Kelas & \multicolumn{1}{c|}{$\mathrm{N}$} & Mean & Std. Deviation & $\begin{array}{c}\text { Std. Error } \\
\text { Mean }\end{array}$ \\
\hline Posttest & Experimental & 30 & 72.50 & 10.808 & 1.973 \\
\hline & Control & 30 & 57.83 & 9.973 & 1.821 \\
\hline
\end{tabular}

The table reveals a difference in mean value between experimental and control group. Experimental group mean was 72.50 and the standard deviation was 10.808. Control group mean was 57.83 and the standard deviation was 9.973. The test achievement test between experimental and control group are different, the researcher conduct t-test. There is significant difference between two groups if sig. (2-tailed) value is the same as or is lower than $5 \%$ or 0.05 . Sig. (2-tailed) value was 0.000 . the result of t-test $=5.463$, and $d f=58$ in equal variances assumed and 57.629 in equal variances not assumed. But, $95 \%$ confidence interval ranging was different. If equal variances assumed was 9.292 to 20.041, and equal variances not assumed was 9.291 to 20.042. The significance different between the mean of both groups is found.

\section{CONCLUSION AND SUGGESTION}

The conclusions can be drawn are as follows; (1) the students' writing achievement in experimental group, which is taught by using Facebook, is in a good category with the mean score 72.50 ; (2) the students' writing achievement in control group, which is not taught by using Facebook, is in fair category with the mean score 57.83 ; (3) there is significant difference between the experimental and control group's achievement, the result show that experimental group's achievement is higher than the control group; and (4) Facebook especially Facebook group is effective to be used in teaching writing descriptive text. The researcher suggest to; the teacher can minimize the students' problems in writing and can improve students' achievement in it by using social media such as Facebook.

\section{REFERENCES}

Brown, H. Douglas. (2000). Principles of Language Learning and Teaching. New York: Longman.

---------------. (2007). Principles of Language Learning and Teaching $5^{\text {th }}$ Edition. New York: Pearson Longman Inc.

Gerot, L. and Wignell, P. (1994). Making Sense of Functional Grammar. Queensland: Antipadean Educational Enterprises Publishing.

Johnson, K. (2001). An Introduction to Foreign Language Learning and Teaching. Harlow: Pearson Education Limited. 
Kane, Thimas, S. (2000). The Oxford Essential Guide to Writing. New York: Barkley Books.

Linse, Caroline T. (2003). Practical English Language Teaching: Young Learners. NY: Mc Graw Hill

Reid, Joy. (2000). The Process of Composition. New York: Prentice Hall.

Westminster, Hub. (2013). Facebook Guide for Educators. London: The Education Foundation

Yunus, M. Md. and Salehi, H. 2012. The Effectiveness of Facebook Groups on Teaching and Improving Writing: Studentse Perceptions. International Journal of Education and Information Technologies. Online. Available at http://www.naun.org/multimedia/NAUN/educationinformation/17-538.pdf [Accesed 01/04/19] 